\title{
Subglottic Cancer pTX TNM Finding v8
}

National Cancer Institute

\section{Source}

National Cancer Institute. Subglottic Cancer pTX TNM Finding v8. NCI Thesaurus. Code C133120.

Subg lottic cancer in which the primary tumor cannot be assessed. (from AJCC 8th Ed.) 